\title{
SADAR PURI UNTUK MENCEGAH DEHIDRASI PADA REMAJA DI SMA NEGERI 5 KOTA JAMBI
}

\author{
Merita $^{1)}$, Djayusmantoko ${ }^{2)}$ \\ 1,2 Program Studi Ilmu Gizi, Sekolah Tinggi Ilmu Kesehatan Baiturrahim, Jambi \\ Email: merita_meri@yahoo.com
}

\begin{abstract}
The reaction in the human body almost requires water. If the body lacks water, it will be associated with dehydration. Therefore, the purpose of this service is to carry out the Self-Urine Check (PURI) counseling in adolescents. This activity was held from May to June 2017, in the SMA 5 Kota Jambi. The target is students of class XI SMA 5 Kota Jambi. This activity consists of giving counseling with power point media, leaflets, posters, and pre-post test questions; practice measuring the scale of hydration using PURI cards and; establishment of a Self-Urine Check. The output of this service activity are: (1) Effective and innovative media / tools / leaflets and modules; (2) Application of conscious PURI and; (3) The formation of a group of mobilizing students aware of PURI. Based on the results of the pre-test it was known that most students did not know that people with more nutritional status were at risk of dehydration (90.9\%), and did not know that men were at higher risk of dehydration than women (81.3\%). However, after being given counseling all targets can answer post-test questions correctly (100\%). Therefore, it is necessary to collaborate with the school with local health agencies in providing health information media and facilities in the school.
\end{abstract}

Keywords: Self-Urine Check, Dehydration, Adolescents

\begin{abstract}
ABSTRAK
Reaksi di dalam tubuh manusia hampir sepenuhnya memerlukan air. Jika tubuh kekurangan air maka akan berhubungan dengan dehidrasi. Oleh karena itu, tujuan pengabdian ini adalah untuk melakukan penyuluhan Sadar Periksa Urin Sendiri (PURI) pada remaja. Kegiatan ini dilaksanakan pada bulan Mei sampai Juni 2017, di SMA Negeri 5 Kota Jambi. Sasaran adalah siswa/siswi kelas XI SMA 5 Kota Jambi. Kegiatan ini terdiri dari (1) pemberian penyuluhan dengan media power point, leaflet, poster, serta soal pre-post test; (2) Praktek pengukuran skala hidrasi menggunakan kartu PURI dan; (3) Pembentukan Tim Penggerak sadar PURI. Luaran dari kegiatan pengabdian ini yaitu: (1) Media/alat/leaflet dan modul yang efektif dan inovatif; (2) Penerapan sadar PURI dan; (3) Terbentuknya kelompok siswa penggerak sadar PURI . Berdasarkan hasil pre-test diketahui bahwa sebagian besar siswa tidak mengetahui bahwa orang dengan status gizi gemuk lebih berisiko mengalami dehidrasi $(88,8 \%)$, dan tidak mengetahui bahwa laki-laki beresiko lebih tinggi mengalami dehidrasi dibandingkan perempuan $(80,0 \%)$. Namun, setelah diberikan penyuluhan semua sasaran dapat menjawab pertanyaan post-test dengan benar (100\%). Oleh karena itu, perlu upaya kerja sama dari pihak sekolah dengan instansi kesehatan setempat dalam penyediaan sarana dan media informasi kesehatan di lingkungan sekolah.
\end{abstract}

Kata kunci: PURI, Dehidrasi, Remaja 


\section{PENDAHULUAN}

Air merupakan bagian terbesar dari komposisi tubuh manusia. Batmanghelidj (2007) menjelaskan bahwa tubuh manusia rata-rata tersusun atas $63 \%, 17 \%$ protein, $13 \%$ lemak, $6 \%$ mineral, $1 \%$ karbohidrat dan vitamin. Seseorang yang kehilangan $40 \%$ lemak dan protein sampai terjadi penurunan berat badan masih mampu bertahan hidup, akan tetapi kehilangan $20 \%$ air dapat menyebabkan kematian.

Reaksi di dalam tubuh manusia hampir sepenuhnya memerlukan air. Air merupakan komponen utama dari semua struktur sel dan merupakan media kelangsungan proses metabolisme dan reaksi kimia di dalam tubuh. Metabolisme tubuh akan berjalan dengan baik, apabila pemenuhan kebutuhan air untuk menggantikan air tubuh yang hilang dapat terpenuhi setiap harinya (Atam, 2005).

$$
\text { Hydration for Health (2010) }
$$
menyatakan bahwa setiap hari, setidaknya 2,6 liter air melalui pernapasan, keringat, feses dan urin. Dalam laporan yang dipublikasikan oleh World Health Organization (WHO) (2005), jumlah asupan air yang diperlukan untuk mempertahankan keseimbangan air untuk rata-rata orang dewasa dalam kondisi normal adalah 2,9 L/Hari untuk laki-laki dan 2,2 L/hari untuk wanita. The European Fodd Safety Authority (EFSA) dan Institute of Medicine (IOM) menyatakan bahwa pola makan rata-rata menyediakan $20 \%$ dari asupan air total yang direkomendasikan.

Sekolah Menengah Atas (SMA) Negeri 5 Kota Jambi merupakan salah satu sekolah negeri yang terdapat di Kota Jambi dengan jumlah siswa/i terbanyak. Sebagian besar remaja di SMA N 5 Kota Jambi kurang mengkonsumsi air $(<2$ liter per hari). Oleh karena itu, tujuan pengabdian ini adalah untuk melakukan penyuluhan Sadar Periksa Urin Sendiri (PURI) pada remaja di SMA N 5 Kota Jambi.

\section{TARGET DAN LUARAN}

1. Target

Kegiatan pengabdian ini memiliki target khusus yaitu:

a. Adanya siswa/siswi kelas XI SMA 5 Kota Jambi

b. Adanya guru penanggung jawab kelas XI SMA 5 Kota Jambi

c. Siswa/i memiliki pengetahuan baik setelah diberikan materi tentang Sadar PURI. Indikator pengetahuan baik yaitu jawaban benar pada pertanyaan post test sebesar $\geq 80 \%$.

2. Luaran

Luaran dari kegiatan pengabdian ini yaitu:

a. Media/alat/leaflet dan modul yang efektif dan inovatif.

b. Penerapan sadar PURI di SMA 5 Kota Jambi.

c. Terbentuknya kelompok siswa penggerak sadar PURI di SMA 5 Kota Jambi.

\section{METODE PELAKSANAAN}

1. Waktu dan Tempat

Kegiatan pengabdian ini dilaksanakan selama 2 bulan pada bulan Mei sampai Juni 2017, di SMA 5 Kota Jambi

2. Tujuan

Tujuan dari kegiatan ini yaitu:

a. Menciptakan media/leaflet dan modul yang efektif dan inovatif dalam menyampaikan pesan sadar PURI pada remaja di SMA N 5 Kota Jambi.

b. Penerapan prinsip sadar PURI pada remaja di SMA N 5 Kota Jambi dalam mencegah hidrasi.

c. Membentuk kelompok siswa penggerak sadar PURI pada remaja di SMA N 5 Kota Jambi.

3. Sasaran

Sasaran dalam kegiatan pengabdian ini adalah siswa/i orang perwakilan setiap 
kelas XI SMA N 5 Kota Jambi yang berjumlah 45 orang.

4. Kontribusi Peserta Pengabdian

a. Menjadi peserta kegiatan pengabdian.

b. Mengikuti pre test dan post test

c. Menyiapkkan diri untuk evaluasi bersama.

d. Menjadi calon tim penggerak sadar PURI pada remaja di SMA N 5 Kota Jambi.

e. Menjadi fasilitator dalam mengajak siswa lainnya untuk menerapkan sadar PURI pada remaja di SMA N 5 Kota Jambi.

5. Pelaksanaan Kegiatan Pengabdian

a. Materi Pelatihan

Materi kegiatan yang dikembangkan berupa power point, leaflet, poster, serta soal pre-post test.

b. Praktek Kegiatan

Metode praktek dilakukan untuk mendukung materi yang telah disampaikan dan mendukung teori dalam mencapai peningkatan perilaku peserta. Praktek yang dilakukan yaitu mengukur skala hidrasi berdasarkan kartu PURI.

c. Pembentukan Tim Penggerak Sadar PURI

Tim Penggerak Sadar PURI terdiri dari siswa/i yang dipilih secara obyektif oleh tim pengabdian.

3. Monitoring dan Evaluasi

Monitoring dan evaluasi (Monev) dilakukan dengan teknik wawancara dan obeservasi langsung kepada sasaran. Cakupan Monev meliputi aspek perencanaan, pelaksanaan kegiatan, hasil kegiatan, dan dampak kegiatan.

\section{HASIL DAN PEMBAHASAN}

SMA Negeri 5 Kota Jambi merupakan salah satu SMA negeri yang berada di Kecamatan Telanaipura, Kota Jambi. Jumlah siswa/siswi di SMA tersebut 1.901 orang dan jumlah guru yaitu 57 orang.

Sasaran dalam kegiatan ini adalah siswa/siswi kelas XI di SMA N 5 Kota Jambi yang berjumlah 15 Kelas. Masingmasing kelas dipilih diwakilkan oleh 3 orang untuk mengikuti kegiatan penyuluhan sehingga jumlah peserta adalah 45 orang. Pada pelaksanaannya semua siswa/i menghadiri kegiatan sampai selesai sehingga capaian sasaran dalam kegiatan ini $100 \%$. Kegiatan ini didampingi oleh guru wali kelas XI sehingga diharapkan guru tersebut dapat mentransformasikan prinsip dasar dalam pemeriksaan urin sendiri kepada siswa/i secara berkesinambungan.

Sebelum dilakukan kegiatan penyuluhan perserta diberikan soal pre-test untuk mengukur pengetahuan awal sebelum diberikan penyuluhan. Pemberian materi disampaikan oleh 1 orang dosen yang ahli dibidang gizi yaitu ketua pengabdian serta dibantu oleh 3 orang mahasiswa dalam pelaksanaan teknik pengabdian. Setelah dilakukan penyuluhan, sasaran diberikan soal post-test untuk mengukur pengetahuan sasaran setelah diberikan penyuluhan. Selain itu, pada pelaksanaan tim pengabdian juga mempraktikkan cara membaca indikator dehidrasi pada kartu PURI yang telah dibagikan kepada siswa/i.

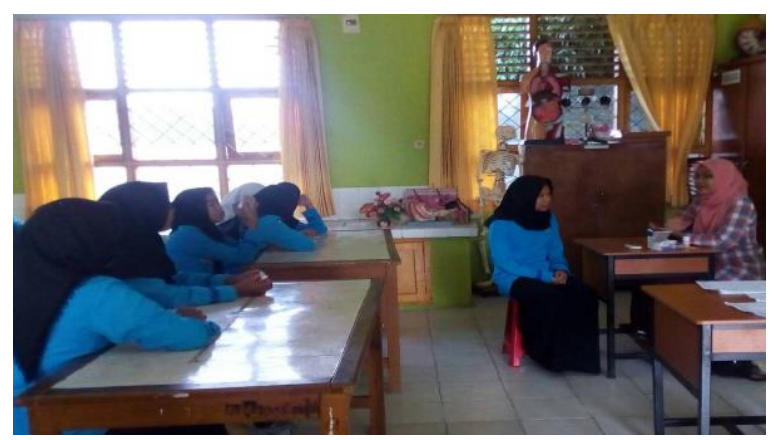

Gambar 1. Kegiatan penyuluhan dan pendampingan 
Pada pelaksanaanya, sasaran merespon dengan baik sehingga ada umpan balik antara pemateri dengan sasaran. Hasil kegiatan ini mendapatkan sebanyak 3 orang siswa (dari 44 siswa/i) terpilih menjadi "siswa sadar PURI" karena dapat mempraktekkan cara membaca indikator dehidrasi menggunakan kartu PURI, serta dapat menjelaskan makna dari tingkatan dehidrasi.

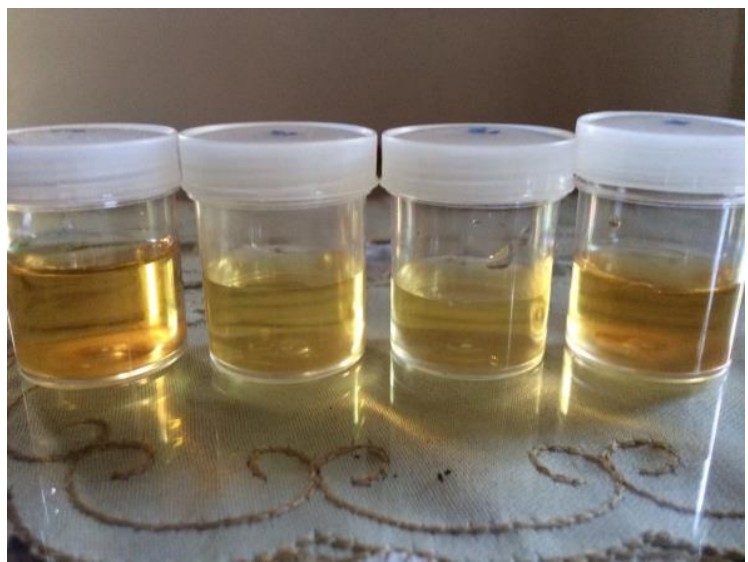

Gambar 2. Kegiatan praktek pengukuran urin menggunakan kartu PURI

Berdasarkan hasil pre-test diketahui bahwa sebanyak 40 siswa/i $(88,8 \%)$ tidak mengetahui bahwa orang dengan status gizi gemuk lebih berisiko mengalami dehidrasi. Dan sebanyak 36 siswa/i (80\%) tidak mengetahui bahwa laki-laki beresiko lebih tinggi mengalami dehidrasi dibandingkan perempuan. Namun, setelah diberikan penyuluhan tentang sadar PURI semua sasaran dapat menjawab pertanyaan posttest dengan benar (100\%).

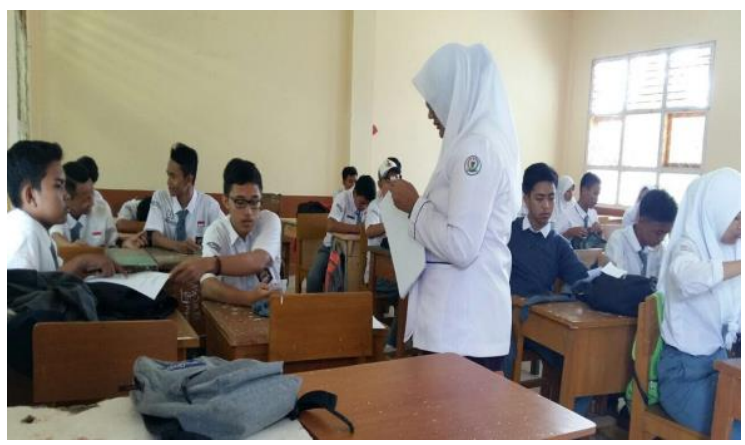

Gambar 3. Pemberian lembar evaluasi penyuluhan (post test)
Diharapkan kepada pihak Sekolah dapat mengoptimalkan peran Unit Kesehatan Sekolah (UKS) dalam memberikan informasi dan pendidikan kesehatan khususnya tentang pentingnya pemeriksaan urin sendiri untuk mencegah terjadinya dehidrasi.

Perlu upaya kerja sama dari pihak sekolah dengan Puskesmas setempat dalam penyediaan sarana informasi seperti poster, leaflet yang menunjang dalam penyampaian informasi tentang kesehatan di lingkungan sekolah.

\section{KESIMPULAN DAN SARAN}

\section{Kesimpulan}

Berdasarkan kegiatan pengabdian yang telah dilaksanakan di SMA Negeri 5 Kota Jambi, maka dapat disimpulkan bahwa:

1) Sebanyak $100 \%$ siswa/i kelas XI menghadiri kegiatan pengabdian masyarakat.

2) Terjadinya perubahan pengetahuan yang baik pada sasaran.

3) Sasaran mampu membaca dan menginterpretasi indikator dehidrasi menggunakan kartu PURI.

4) Terpilih 3 orang siswa menjadi siswa sadar PURI.

\section{Saran}

Kepada pihak Sekolah disarankan dapat mengoptimalkan peran Unit Kesehatan Sekolah (UKS) dalam memberikan informasi dan pendidikan kesehatan khususnya tentang pentingnya pemeriksaan urin sendiri untuk mencegah terjadinya dehidrasi.

\section{UCAPAN TERIMAKASIH}

Terimakasih disampaikan kepada Sekolah Tinggi Ilmu Kesehatan Baiturrahim yang telah memberikan dukungan dana sehingga kegiatan ini dapat terlaksana dengan baik. 
Jurnal Abdimas Kesehatan (JAK) Vol 1,No.1,Januari 2019

p-ISSN: 2655-9226

e-ISSN: 2655-9218

\section{DAFTAR PUSTAKA}

Batmanghelidj F. 2007. Air untuk Menjaga Kesehatan dan Menyembuhkan Penyakit. Jakarta: Gramedia Pustaka Utama.

European Food Safety Authority (EFSA). 2010. Scientific Opinion on Dietary Reference Values for water. EFSA Journal 2010; 8(3):1459

[WHO] World Health Organization. 2005. Nutrients in drinking water. Geneva.

[WHO] World Health Organization. 2010. Global Recommendations on Physical Activity for Health. http://www.who.int/dietphysicalactivity /factsheet_recommendations/en/. 